Journal of Research in Interprofessional Practice and

Education

Vol. 11.1

2021

\title{
The Acceptability of Physiotherapy Care in Emergency Departments: An Exploratory Survey of Emergency Department Physicians
}

\author{
Eveline Matifat, PT, $\mathbf{M S c ^ { a }}$, Pascale Lavoie-Côté, PT, $\mathbf{M S c}^{\mathrm{b}}$ \\ Nabila Kounda, PT, MSc ${ }^{b}$, Lorie Charrier, PT, MSc $^{\mathrm{b}}$, \\ Kadija Perreault, PT, PhD ${ }^{c, d}$, François Desmeules, PT, PhD ${ }^{a, b}$
}

\footnotetext{
a. Orthopedic Clinical Research Unit, MaisonneuveRosemont Hospital Research Center, University of Montreal Affiliated Research Center, Montréal, QC, Canada;

b. School of Rehabilitation, Faculty of Medicine, University of Montréal, Montréal, QC, Canada;

c. Center for

Interdisciplinary Research in

Rehabilitation and Social Integration (CIRRIS), Québec, QC, Canada;

d. Departement of

Rehabilitation, Faculty of Medicine, Laval

University, Québec, QC, Canada
}

\begin{abstract}
Background: Interprofessional emergency department (ED) models of care, including physiotherapists, have emerged to answer growing demands for ED care. The purpose of this study was to assess the perceptions of ED physicians regarding ED physiotherapy.

Methods and findings: Ninety-five ED physicians, members of one of two ED physicians' associations in the province of Québec, completed a survey (response rate $=14.7 \%$ ). Most had a positive perception of physiotherapists' competencies $(96.8 \%)$ and were confident that ED physiotherapy care is safe and efficient (96.8\%).

Conclusions: Based on responses from this limited sample, ED physicians have a positive perception of ED physiotherapy models of care.

Keywords: Emergency department; Physiotherapy; Advanced practice physiotherapy; Acceptability; Models of care
\end{abstract}

Journal of Research in Interprofessional Practice and Education (JRIPE)

Vol. 11.1

(C) 2021

doi:10.22230/jripe.2021

v11n1a321

Corresponding author: François Desmeules. Email:f.desmeules@ umontreal.ca

\section{Background}

Over the past few decades, increasing pressure on healthcare systems has made healthcare transformations a priority [1-4]. These transformations have resulted in the development of new collaborative models of care in which healthcare practitioners are able to practice to the maximum scope of their profession and training, as well as perform roles or acts traditionally carried out by medical providers. Such initiatives have required innovation and close collaboration among providers and have resulted in the emergence of new interprofessional models of care. Within these new models of care, interprofessional collaboration has emerged as a key element of optimizing patient care. Mounting evidence supports the integration of non-physician healthcare professionals in more autonomous roles to improve access to care in primary or secondary care settings $[5,6]$. Internationally, overburdened emergency departments (EDs) have been targeted as a major concern for timely and efficient healthcare delivery, especially with the aging population and the 
2

The Acceptability of Emergency Department Physiotherapy

Matifat, LavoieCôté, Kounda, Charrier, Perreault, \& Desmeules

Journal of Research in Interprofessional Practice and Education

Vol. 11.1

2021 increased prevalence of chronic diseases [7]. Physiotherapists have emerged as key healthcare providers in new collaborative models of care implemented in EDs. With their extensive training in various areas, such as musculoskeletal disorders (MSKDs), geriatrics, burns, and vestibular disorders, physiotherapists can provide care to a wide range of patients presenting to the ED. In the last decade, usual physiotherapy or advanced practice physiotherapy (APP) models of care, have emerged in EDs worldwide. In Australia and the United Kingdom, APP are already involved in the autonomous evaluation, treatment, and discharge of ED patients. In Australia, studies have shown that physiotherapists can safely and efficiently treat ED patients with musculoskeletal injuries and reduce wait time, treatment time, and length of stay compared to usual medical care [8-11]. Several studies demonstrated greater satisfaction with ED physiotherapy care [8,12-14] compared to usual ED care. Access to early rehabilitation and close collaboration with ED physicians may be considered beneficial for the patient and would likely have positive outcomes in terms of health services organization and the efficacy of care.

The implementation of new models of care in a setting such as the ED can be challenging, as the care strongly relies on an efficient collaboration between various healthcare practitioners. Indeed, the introduction of multidisciplinary care based on efficient teamwork within the ED has been shown to contribute to improving access to care, and physiotherapists have a significant role to play within these models of care [15]. The support of ED physicians is one of the mainstays of achieving the efficient implementation of ED physiotherapy care [16-17]. In the literature currently available on this topic, physiotherapists are usually well perceived by other ED healthcare providers, such as physicians and nurses $[16,18,19]$. They are mostly recognized for their added value when it comes to the care of persons with MSKD $[16,17]$. However, ED health professionals do not always know the depth of the skills and expertise of physiotherapists $[16,17,18]$. Since ED physicians' perception of physiotherapy care is an important factor in either helping or impeding the implementation of such collaborative models of care in this context of practice, it is crucial to evaluate the perspective of ED physicians regarding the acceptability of this model. There are currently no studies assessing the perceptions of ED physicians in Canada regarding ED physiotherapy care. Thus, the objective of this study was to assess the perceptions of ED physicians regarding the acceptability of physiotherapy care in an ED setting.

\section{Methods}

\section{Study design}

This descriptive study used a cross-sectional survey design and was approved by the Health Research Ethic Committee of Maisonneuve-Rosemont Hospital Research Centre in Montréal, Canada (\#2020-1928).

\section{Target population}

This survey used a convenience sample targeting ED physicians who are members of either the Association des médecins d'urgence du Québec (AMUQ) or the Association des spécialistes en médecine d'urgence du Québec (ASMUQ). In 
The Acceptability of Emergency Department Physiotherapy

Matifat, LavoieCôté, Kounda, Charrier, Perreault, \& Desmeules
Journal of Research in Interprofessional Practice and Education

Vol. 11.1

2021

\section{Journal of Research in Interprofessional Practice and Education}

December 2019, an email including a link to an online questionnaire was sent to all 533 members of the AMUQ, which represents ED physicians or medical students completing a residency in ED care. The email detailed the purpose of this study as well as the procedure to complete the survey (see Appendix 1). A reminder email was sent three weeks after the initial invitation. In January 2020, an email including a link to an online questionnaire was sent to all 180 members of the ASMUQ, and a reminder was sent two weeks later. No compensation was offered to participants. No personal data that could identify participants was collected. The SurveyMonkey [20] web platform was used to administer the survey. This platform is secure, using an SSL/TLS for data encryption.

\section{Questionnaire development}

The survey was developed based on the currently available literature regarding ED physiotherapy [6], the acceptability of physiotherapy and APP in primary care settings [21], as well as previous surveys successfully conducted by this team on related topics [21,22].

The questionnaire included a total of 27 questions divided into four sections:

1. Demographic characteristics and ED work context description

2. Experience working in collaboration with physiotherapists

3. Perception and acceptability of ED usual physiotherapy care

4. Perception and acceptability of APP care in the ED

The survey was preceded by a short text informing the participant about the topic and objectives of this survey, as well as a general description of ED physiotherapy care. A description of usual ED physiotherapy and APP models of care and scope of practice was provided at the beginning of each section (see Appendix 2). The questionnaire used multiple choice questions for the majority of questions and either 5- or 6-point Likert scale response options.

\section{Analysis}

Raw data were exported into an Excel spreadsheet. Descriptive analyses were first conducted with calculations of frequency distributions, means, and standard deviations. For some questions with a 5- or 6-point Likert scale, answers from the first and last categories were merged, thus leaving the scale with two response categories to allow cross tabulation and testing according to selected respondents' characteristics. Chi square $\left(\chi^{2}\right)$ and Fisher's exact tests were performed to compare responses across demographic characteristics, previous experience with physiotherapy care, and other select questions. The alpha level was set at 0.05 . Statistical analyses were performed using SPSS (version 25).

\section{Results}

Of the targeted ED physicians, 103 undertook the survey, 91 fully completed it, four partially completed it, and eight opened the survey but did not enter any information. Only responses from participants who either partially or fully completed the survey were considered for analysis $(n=95)$. This resulted in a completion rate of 88.3 percent and a participation rate of 14.7 percent. 


\section{JRIPE}

4

The Acceptability of Emergency Department Physiotherapy

Matifat, LavoieCôté, Kounda, Charrier, Perreault, \& Desmeules

Forty-two participants were male (44.2\%), and the majority of the participants were 35 years old or older $(n=61,64.2 \%)$. Fifty participants had less than 10 years of experience as an ED physician (52.6\%), and 45 had 10 years or more experience (47.4\%) (see Table 1). When asked about their previous professional experience with physiotherapy care, the majority of participants $(n=62,65.3 \%)$ had referred patients to physiotherapy care within the last twelve months, but only 36 of them (37.9\%) had collaborated with a physiotherapist in an ED setting during the same period (see Table 1).

Table 1: Demographic data, practice context, and previous experience with physiotherapy care $(n=95)$

\begin{tabular}{|c|c|c|c|}
\hline \multicolumn{2}{|l|}{ Questions } & $\begin{array}{l}\text { Collected data } \\
\%(n)\end{array}$ & $\begin{array}{l}\text { Recategorized data for analyses } \\
\text { (if applicable) } \%(n)\end{array}$ \\
\hline Gender & $\begin{array}{l}\text { Male } \\
\text { Female } \\
\text { Other }\end{array}$ & $\begin{array}{l}44.2(42) \\
55.8(53)\end{array}$ & \\
\hline Age & $\begin{array}{l}18-24 \text { years old } \\
25-34 \text { years old } \\
35-44 \text { years old } \\
45-54 \text { years old } \\
55-64 \text { years old } \\
\geq 65 \text { years old }\end{array}$ & $\begin{array}{c}1.1 \quad(1) \\
34.7(33) \\
23.2(22) \\
18.9(18) \\
20.0(19) \\
2.1(2)\end{array}$ & $\begin{array}{l}<35 \text { years old: } 35.8(34) \\
\geq 35 \text { years old: } 64.2(61)\end{array}$ \\
\hline $\begin{array}{l}\text { Clinical experience in } \\
\text { the ED }\end{array}$ & $\begin{array}{l}<1 \text { year } \\
1-4 \text { years } \\
5-9 \text { years } \\
10-20 \text { years } \\
>20 \text { years }\end{array}$ & $\begin{array}{r}8.4(8) \\
23.2(22) \\
21.0(20) \\
17.9(17) \\
29.5(28)\end{array}$ & $\begin{array}{l}<10 \text { years: } 52.6(50) \\
\geq 10 \text { years: } 47.4(45)\end{array}$ \\
\hline $\begin{array}{l}\text { Referral to physiotherapy } \\
\text { care in any context of care } \\
\text { within the last } 12 \text { months }\end{array}$ & $\begin{array}{l}\text { Frequently } \\
\text { Occasionally } \\
\text { Rarely } \\
\text { Never } \\
\text { I don't know }\end{array}$ & $\begin{array}{c}35.8(34) \\
29.5(28) \\
15.8(15) \\
18.9(18) \\
0.0(0)\end{array}$ & $\begin{array}{l}\text { Frequently or occasionally: } 65.3 \text { (62) } \\
\text { Rarely or never: } 34.7 \text { (33) }\end{array}$ \\
\hline $\begin{array}{l}\text { Collaboration with an ED } \\
\text { physiotherapist within the } \\
\text { last } 12 \text { months }\end{array}$ & $\begin{array}{l}\text { Frequently } \\
\text { Occasionally } \\
\text { Rarely } \\
\text { Never } \\
\text { I don't know }\end{array}$ & $\begin{array}{r}21.1(20) \\
16.8(16) \\
25.3(24) \\
36.8(35) \\
0.0(0)\end{array}$ & $\begin{array}{l}\text { Frequently or occasionally: } 37.9 \text { (36) } \\
\text { Rarely or never: } 62.1 \text { (59) }\end{array}$ \\
\hline
\end{tabular}

Note: $\mathrm{ED}=$ emergency department

Journal of Research in Interprofessional Practice and Education

Vol. 11.1

2021
Participants had a positive opinion of physiotherapists' overall competencies regardless of the clinical practice setting $(n=91,96.8 \%)$, and the majority of participants perceived that physiotherapists were either very competent or competent enough to practice in an ED setting $(n=71,75.5 \%)$. When asked about the impact of usual physiotherapy care in the ED, the majority were confident that physiothera- 


\section{JRIPE}

5

The Acceptability of Emergency Department Physiotherapy

Matifat, LavoieCôté, Kounda, Charrier, Perreault, \& Desmeules

pists would provide safe and efficient care $(n=91,96.8 \%)$ and that they could improve care for ED patients ( $n=76,80.9 \%$ ) (see Table 2). Participants identified the following as the most relevant conditions for which to refer to an ED physiotherapist: mobility disorders or falls $(n=88,93.6 \%)$, MSKDs $(n=83,88.3 \%)$, geriatric disorders $(n=81,86.2 \%)$, balance disorders $(n=76,80.9 \%)$, neurological disorders $(n=48,51.1 \%)$, and respiratory disorders $(n=22,23.4 \%)$ (see Table 2$)$.

\section{Table 2: Perceptions and acceptability of emergency department usual physiotherapy care $(n=94)^{*}$}

\begin{tabular}{|c|c|c|c|}
\hline \multicolumn{2}{|l|}{ Questions } & $\begin{array}{l}\text { Collected data } \\
\%(n)\end{array}$ & $\begin{array}{l}\text { Recategorized data for analyses } \\
\text { (if applicable) } \%(n)\end{array}$ \\
\hline $\begin{array}{l}\text { Perception of the overall } \\
\text { competency of physiother- } \\
\text { apists not withstanding } \\
\text { the practice context }\end{array}$ & $\begin{array}{l}\text { Very competent } \\
\text { Competent } \\
\text { A little competent } \\
\text { Not at all competent } \\
\text { I don't know }\end{array}$ & $\begin{array}{r}46.8(44) \\
50.0(47) \\
3.2(3) \\
0.0(0) \\
0.0(0)\end{array}$ & $\begin{array}{l}\text { Very competent or competent: } \\
96.8 \text { (91) } \\
\text { Little or not competent: } \\
3.2 \text { (3) }\end{array}$ \\
\hline $\begin{array}{l}\text { Perception of the compe- } \\
\text { tency of physiotherapists } \\
\text { in the ED }\end{array}$ & $\begin{array}{l}\text { Very competent } \\
\text { Competent } \\
\text { A little competent } \\
\text { Not at all competent } \\
\text { I don't know }\end{array}$ & $\begin{array}{r}29.8(28) \\
45.7(43) \\
12.8(12) \\
2.1(2) \\
9.6(9)\end{array}$ & $\begin{array}{l}\text { Very competent or competent: } \\
75.5 \text { (71) } \\
\text { Little or not competent: } \\
14.9 \text { (14) }\end{array}$ \\
\hline $\begin{array}{l}\text { Confidence regarding the } \\
\text { efficacy and safety of usual } \\
\text { physiotherapy care in the } \\
\text { ED }\end{array}$ & $\begin{array}{l}\text { Extremely confident } \\
\text { Very confident } \\
\text { Moderately confident } \\
\text { A little confident } \\
\text { Not at all confident } \\
\text { I don't know }\end{array}$ & $\begin{aligned} 26.6(25) \\
55.3(52) \\
14.8(14) \\
1.1(1) \\
1.1(1) \\
1.1 \quad(1)\end{aligned}$ & $\begin{array}{l}\text { Extremely, very, } \\
\text { or moderately confident: } \\
96.7 \text { (91) } \\
\text { Little or not confident: } \\
2.1 \text { (2) }\end{array}$ \\
\hline $\begin{array}{l}\text { Usual physiotherapy care } \\
\text { can contribute to improve } \\
\text { care for ED patients }\end{array}$ & $\begin{array}{l}\text { Strongly agree } \\
\text { Agree } \\
\text { Neither agree nor disagree } \\
\text { Disagree } \\
\text { Strongly disagree } \\
\text { I don't know }\end{array}$ & $\begin{array}{r}39.3(37) \\
41.5(39) \\
16.0(15) \\
0.0(0) \\
1.1(1) \\
2.1 \quad(2)\end{array}$ & $\begin{array}{l}\text { Strongly agree or agree: } \\
80.8 \text { (76) } \\
\text { Neutral, disagree, or strongly } \\
\text { disagree: } 17.1 \text { (16) }\end{array}$ \\
\hline $\begin{array}{l}\text { What types of health con- } \\
\text { ditions do you think it is } \\
\text { relevant to refer to an ED } \\
\text { physiotherapist for?** }\end{array}$ & $\begin{array}{l}\text { Musculoskeletal disorders } \\
\text { Balance disorders } \\
\text { Neurological disorders } \\
\text { Mobility disorders and falls } \\
\text { Geriatric disorders and } \\
\text { deconditioning } \\
\text { Respiratory disorders } \\
\text { Other }\end{array}$ & $\begin{array}{r}88.3(83) \\
80.9(76) \\
51.1(48) \\
93.6(88) \\
86.2(81) \\
23.4(22) \\
9.6(9)\end{array}$ & \\
\hline
\end{tabular}

Journal of Research in Interprofessional Practice and Education

Vol. 11.1 2021
Notes: *Missing data: $n=1$; ${ }^{* *}$ More than one answer possible; total over $100 \%$; ED = emergency department

In regard to APP care in the ED (see Table 3), participants were confident that physiotherapists could provide autonomous care to patients with MSKDs $(n=80$, 
JRIPE

6

The Acceptability of Emergency Department Physiotherapy

Matifat, LavoieCôté, Kounda, Charrier, Perreault, \& Desmeules

87.9\%) and that they would appropriately refer the patient to a physician if required $(n=83,91.2 \%)$. In terms of prescriptions, a large majority of respondents were confident that physiotherapists could appropriately prescribe X-rays $(n=77,84.6 \%)$, as well as other medical imaging tests $(n=62,68.1 \%)$ and medication $(n=69,75.8 \%)$. The majority of respondents were confident that advanced practice physiotherapists could appropriately perform injections, either intra-muscular or intra-articular, if required for a patient's condition $(n=61,67.0 \%)$. In terms of APP care for patients presenting to the ED with an MSKD, 75 percent of participants agreed that APP care could contribute to improved care delivery for ED patients $(n=68), 65$ percent of participants did not believe APP care could reduce rates of medical imaging prescriptions $(n=59), 68$ percent of participants agreed that APP care could help reduce waiting times in the ED $(n=62)$, and 73 percent of participants agreed that with advanced practice physiotherapists managing ED patients with MSKDs, physicians would have more time to care for other patients requiring medical attention $(n=66)$ (see Table 3$)$.

\section{Table 3: Perceptions of the acceptability of advanced practice physiotherapy care in emergency departments $(n=91)^{*}$}

\begin{tabular}{|l|l|c|l|}
\hline \multicolumn{2}{|l|}{ Questions } & $\begin{array}{l}\text { Collected data } \\
\%(n)\end{array}$ & $\begin{array}{l}\text { Recategorized data for analyses } \\
\text { (if applicable) \% (n) }\end{array}$ \\
\hline Confidence that an advanced & Extremely confident & $19.8(18)$ & Extremely, very, or moderately \\
practice physiotherapist could & Very confident & $41.7(38)$ & confident: 87.9 (80) \\
appropriately and autonomously & Moderately confident & $26.4(24)$ & \\
diagnose and treat patients with & A little confident & $7.7(7)$ & Little or not confident: 11.0 (10) \\
MSKD & Not at all confident & $3.3(3)$ & \\
& I don't know & $1.1(1)$ & \\
\hline Confidence that the advanced & Extremely confident & $16.5(15)$ & Extremely, very, or moderately \\
practice physiotherapist would & Very confident & $45.0(41)$ & confident: 91.2 (83) \\
appropriately refer back to a & Moderately confident & $29.7(27)$ & \\
physician any patient needing & A little confident & $4.4(4)$ & Little or not confident: \\
medical care & Not at all confident & $3.3(3)$ & 7.7 (7) \\
& I don't know & $1.1(1)$ & \\
\hline Confidence that the advanced & Extremely confident & $13.2(12)$ & Extremely, very, or moderately \\
practice physiotherapist would & Very confident & $43.9(40)$ & confident: 84.6 (77) \\
appropriately prescribe X-rays & Moderately confident & $27.5(25)$ & \\
when deemed necessary for & A little confident & $9.9(9)$ & Little or not confident: \\
patients with MSKD & Not at all confident & $4.4(4)$ & 14.3 (13) \\
& I don't know & $1.1(1)$ & \\
\hline Confidence that the advanced & Extremely confident & $8.8(8)$ & Extremely, very, or moderately \\
practice physiotherapist would & Very confident & $22.0(20)$ & confident: 68.1 (62) \\
appropriately prescribe imaging & Moderately confident & $37.3(34)$ & \\
tests other than X-rays when & A little confident & $19.8(18)$ & Little or not confident: \\
deemed necessary for patients & Not at all confident & $11.0(10)$ & 30.8 (28) \\
with MSKD & I don't know & $1.1(1)$ & \\
& & & \\
\hline
\end{tabular}

Journal of Research in Interprofessional Practice and Education

Vol. 11.1

2021 
JRIPE

7

The Acceptability of Emergency Department Physiotherapy

Matifat, LavoieCôté, Kounda, Charrier, Perreault, \& Desmeules
Journal of Research in Interprofessional Practice and Education

Vol. 11.1

2021
Journal of Research in Interprofessional Practice and Education

Table 3 (continued)

\begin{tabular}{|c|c|c|c|}
\hline \multicolumn{2}{|l|}{ Questions } & \multirow{2}{*}{$\begin{array}{l}\text { Collected data } \\
\%(n) \\
8.8(8) \\
35.1(32) \\
31.9(29) \\
14.3(13) \\
7.7(7) \\
2.2(2)\end{array}$} & \multirow{2}{*}{$\begin{array}{l}\text { Recategorized data for analyses } \\
\text { (if applicable) \% ( } n \text { ) }\end{array}$} \\
\hline $\begin{array}{l}\text { Confidence that the advanced } \\
\text { practice physiotherapist could } \\
\text { appropriately prescribe certain } \\
\text { medications, excluding opioids, } \\
\text { for patients with MSKD }\end{array}$ & $\begin{array}{l}\text { Extremely confident } \\
\text { Very confident } \\
\text { Moderately confident } \\
\text { A little confident } \\
\text { Not at all confident } \\
\text { I don't know }\end{array}$ & & \\
\hline $\begin{array}{l}\text { Confidence that the advanced } \\
\text { practice physiotherapist could per- } \\
\text { form either intra-muscular or } \\
\text { intra-articular injections when rel- } \\
\text { evant for patients with MSKD }\end{array}$ & $\begin{array}{l}\text { Extremely confident } \\
\text { Very confident } \\
\text { Moderately confident } \\
\text { A little confident } \\
\text { Not at all confident } \\
\text { I don't know }\end{array}$ & $\begin{array}{r}6.6(6) \\
27.4(25) \\
33.0(30) \\
20.9(19) \\
5.5(5) \\
6.6(6)\end{array}$ & $\begin{array}{l}\text { Extremely, very, or moderately } \\
\text { confident: } 67.0 \text { (61) } \\
\text { Little or not confident: } 26.4 \text { (24) }\end{array}$ \\
\hline $\begin{array}{l}\text { APP care could improve care path- } \\
\text { ways in the ED for patients with } \\
\text { MSKD }\end{array}$ & $\begin{array}{l}\text { Strongly agree } \\
\text { Agree } \\
\text { Neither agree nor disagree } \\
\text { Disagree } \\
\text { Strongly disagree } \\
\text { I don't know }\end{array}$ & $\begin{array}{cc}30.7 & (28) \\
44.0(40) \\
9.9 & (9) \\
8.8 & (8) \\
4.4 & (4) \\
2.2 & (2)\end{array}$ & $\begin{array}{l}\text { Strongly agree or agree: } \\
74.7 \text { (68) } \\
\text { Neutral, disagree, or strongly } \\
\text { disagree: } 23.1 \text { (21) }\end{array}$ \\
\hline $\begin{array}{l}\text { Management by an advanced } \\
\text { practice physiotherapist of ED } \\
\text { patients with MSKD would reduce } \\
\text { the number of imaging tests pre- } \\
\text { scribed }\end{array}$ & $\begin{array}{l}\text { Strongly agree } \\
\text { Agree } \\
\text { Neither agree nor disagree } \\
\text { Disagree } \\
\text { Strongly disagree } \\
\text { I don't know }\end{array}$ & $\begin{array}{r}12.1(11) \\
18.7(17) \\
35.1(32) \\
17.6(16) \\
12.1(11) \\
4.4(4)\end{array}$ & $\begin{array}{l}\text { Strongly agree or agree: } \\
30.8 \text { (28) } \\
\text { Neutral, disagree, or strongly dis- } \\
\text { agree: } 64.8 \text { (59) }\end{array}$ \\
\hline $\begin{array}{l}\text { Management by an advanced } \\
\text { practice physiotherapist could } \\
\text { reduce wait times for ED patients } \\
\text { with MSKD }\end{array}$ & $\begin{array}{l}\text { Strongly agree } \\
\text { Agree } \\
\text { Neither agree nor disagree } \\
\text { Disagree } \\
\text { Strongly disagree } \\
\text { I don't know }\end{array}$ & $\begin{aligned} 26.4(24) \\
41.7(38) \\
19.8(18) \\
4.4(4) \\
4.4(4) \\
3.3(3)\end{aligned}$ & $\begin{array}{l}\text { Strongly agree or agree: } \\
68.1 \text { (62) } \\
\text { Neutral, disagree, or strongly } \\
\text { disagree: } 28.6(26)\end{array}$ \\
\hline $\begin{array}{l}\text { Management of ED patients with } \\
\text { MSKD by an advanced practice } \\
\text { physiotherapist would allow physi- } \\
\text { cians to have more time to care for } \\
\text { patients requiring medical atten- } \\
\text { tion }\end{array}$ & $\begin{array}{l}\text { Strongly agree } \\
\text { Agree } \\
\text { Neither agree nor disagree } \\
\text { Disagree } \\
\text { Strongly disagree } \\
\text { I don't know }\end{array}$ & $\begin{array}{ll}23.1(21) \\
49.4(45) \\
18.7(17) \\
2.2(2) \\
3.3(3) \\
3.3 & (3)\end{array}$ & $\begin{array}{l}\text { Strongly agree or agree: } 72.5 \\
\text { (66) }\end{array}$ \\
\hline
\end{tabular}

Notes: *Missing data: $n=4 ; \mathrm{APP}=$ advanced practice physiotherapist; MSKD = musculoskeletal disorders; $\mathrm{ED}=$ emergency department

For every question included in this survey, no significant differences in response proportions were found according to participants' age, gender, or previous collab- 
8

The Acceptability of Emergency Department Physiotherapy

Matifat, LavoieCôté, Kounda, Charrier, Perreault, \& Desmeules

Journal of Research in Interprofessional Practice and Education

Vol. 11.1

2021 oration with a physiotherapist either in the ED or outside an ED context $(p \geq 0.05)$. Only one significant difference in response proportions was found in terms of the clinical experience of the participants, with those with 10 years or more of experience being significantly more confident with advanced practice physiotherapists performing injections for patients with MSKDs than those with less than 10 years of experience $(p=0.046)$. No other significant differences were found in regard to participants' clinical experience $(p \geq 0.05)$.

\section{Discussion}

This exploratory study is the first to assess the acceptability of ED physiotherapy care according to Canadian ED physicians. Overall, ED physicians have a positive perception and high acceptability of ED physiotherapy models of care, but some areas of practice seemed to demonstrate lower acceptability.

ED physicians have a positive perception regarding physiotherapists' general competencies as well as specific competencies in terms of care for ED patients. In regard to the optimization of resources usage, ED physicians believed that physiotherapy care could help in many aspects, such as improving care pathways by reducing the number of treating professionals seen, reducing wait times in the ED, and allowing ED physicians to have more time to care for other patients needing their attention. However, most physicians did not agree that ED physiotherapists could help reduce the rates of medical imaging tests prescribed in an ED context. However, current literature on this topic shows that medical imaging is overutilized in the ED $[23,24]$ and that physiotherapists could help reduce some part of medical imaging rates within this context [25].

ED physicians also identified many types of patients who could benefit from having physiotherapists contribute to their care, including geriatric patients, falls, mobility disorders, and MSKDs, all of which represent a significant proportion of ED visits. This indicates that ED physiotherapy care could be of use for a significant proportion of ED patients. The fact that physicians have identified such a broad range of conditions is interesting, and such findings may help promote a more extensive use of physiotherapists.

When looking at respondent characteristics that may influence physician perspectives, the only one that seemed to have some impact was clinical experience. Indeed, physicians with more experience were significantly more confident in advanced practice physiotherapists performing injections for patients with an MSKD. This could be attributed to the fact that they might have more experience working with physiotherapists, thus increasing their confidence in them performing certain medical acts. No other significant differences in perceptions in regard to practice characteristics were found, but this might be due to the small sample size. A study with a larger sample size might shed light on some characteristics of ED physicians that may impact their perception of ED physiotherapy care.

Since efficient teamwork is a cornerstone of ED care, the results from this survey could also be of interest to provide more education to the various members of the ED team, including ED physicians, regarding the impacts and aspects of the successful 
9

The Acceptability of Emergency Department Physiotherapy

Matifat, LavoieCôté, Kounda, Charrier, Perreault, \& Desmeules
Journal of Research in Interprofessional Practice and Education

Vol. 11.1

2021 implementation of physiotherapy care within ED models of care. Further education on the scope of practice of physiotherapists, their potential impact on the quality and efficiency of care for ED patients, as well as their contribution to easing access to care could be provided to the various ED providers, which could facilitate the implementation of new models of care and improve collaboration within these models. Indeed, both efficient collaboration and communication are essential to effective ED care and have been shown to improve patient safety and reduce wait times [15]. As such, further studies on the barriers and facilitators to the collaboration between ED providers could be of interest to inform the implementation of such models of care.

The main limitation of this exploratory study is the low response rate $(14.7 \%)$, which limits the generalization of these findings. Still, this participation rate must be interpreted cautiously since a proportion of respondents were members of both associations and the associations were unable to specify what proportion of their members were affiliated with both, which was the case for almost a third $(n=30)$ of participants. However, since the literature on ED physicians' perceptions regarding the acceptability of ED physiotherapy care is scarce and, to our knowledge, no data were available for Canada on this topic, the results of this exploratory survey are of importance to guide further investigation of this topic. Last, although this survey was developed based on the currently available literature regarding ED physiotherapy [6], the acceptability of physiotherapy and APP in primary care settings [21], and previous surveys successfully conducted by this team on related topics $[21,22]$, its validity has not been formally evaluated.

\section{Conclusion}

The findings of this study provide preliminary data on the acceptability of novel models of care in the ED implicating physiotherapists. These results show that there is a generally positive perception and high acceptability of physiotherapy care in the ED, according to ED physicians. Further studies with larger sample sizes would be of great value to fully assess the perception of ED physicians on this topic. Greater promotion of the scope of practice and skills of physiotherapists in an ED context should be considered and might facilitate the implementation of new physiotherapy models of care in EDs across Canada.

\section{Acknowledgements}

This study could not have been completed without the collaboration of the AMUQ and the ASMUQ and all the participants who completed the survey.

\section{References}

1. Trypuc, J., Hudson, A., \& MacLeod, H. (2006). Ontario's wait time strategy: Part 1. Healthcare Quarterly, 9(2), 44-51, 2.

2. Shipton, D., Badley, E.M., \& Mahomed, N.N. (2003). Critical shortage of orthopaedic services in Ontario, Canada. The Journal of Bone and Joint Surgery, 85-A(9), 1710-1725.

3. Robarts, S., Kennedy, D., MacLeod, A.M., Findlay, H., \& Gollish, J. (2008). A framework for the development and implementation of an advanced practice role for physiotherapists that improves access and quality of care for patients. Healthcare Quarterly, 11(2), 67-75.

4. Ontario. (n.d.). New roles in healthcare. Toronto, ON: Health Force Ontario, Ministry of Health and Long-Term Care. URL: http://www.healthforceontario.ca/WhatIsHFO/NewRoles.aspx [November 2020]. 
10

The Acceptability of Emergency Department Physiotherapy

Matifat, LavoieCôté, Kounda, Charrier, Perreault, \& Desmeules

Journal of Research in Interprofessional Practice and Education

Vol. 11.1

2021
5. Ojha, H.A., Snyder, R.S., \& Davenport, T.E. (2014). Direct access compared with referred physical therapy episodes of care: A systematic review. Physical Therapy, 94(1), 14-30.

6. Matifat, E., Mequignon, M., Cunningham, C., Blake, C., Fennelly, O., \& Desmeules, F. (2019). Benefits of musculoskeletal physicial therapy in emergency departments: A systematic review. Physical Therapy, 99(9), 1150-1166.

7. Bombardier, C., Hawker, G., \& Mosher, D. (2011). The impact of arthritis in Canada: Today and over the next 30 years. Toronto, ON: Arthritis Alliance of Canada.

8. Taylor, N.F., Norman, E., Roddy, L., Tang, C., Pagram, A., \& Hearn, K. (2011). Primary contact physiotherapy in emergency departments can reduce length of stay for patients with peripheral musculoskeletal injuries compared with secondary contact physiotherapy: A prospective nonrandomised controlled trial. Physiotherapy, 97(2), 107-114.

9. Gill, S.D., \& Stella, J. (2013). Implementation and performance evaluation of an emergency department primary practitioner physiotherapy service for patients with musculoskeletal conditions. Emergency Medecine Australasia, 25(6), 558-564.

10. Sutton, M., Govier, A., Prince, S., \& Morphett, M. (2015). Primary-contact physiotherapists manage a minor trauma caseload in the emergency department without misdiagnoses or adverse events: An observational study. Journal of Physiotherapy, 61(2), 77-80.

11. Bird, S., Thompson, C., \& Williams, K.E. (2016). Primary contact physiotherapy services reduce waiting and treatment times for patients presenting with musculoskeletal conditions in Australian emergency departments: An observational study. Journal of Physiotherapy, 62(4), 209-214.

12. Lau, P.M., Chow, D.H., \& Pope, M.H. (2008). Early physiotherapy intervention in an accident and emergency department reduces pain and improves satisfaction for patients with acute low back pain: A randomised trial. Australian Journal of Physiotherapy, 54(4), 243-249.

13. McClellan, C.M., Greenwood, R., \& Benger, J.R. (2006). Effect of an extended scope physiotherapy service on patient satisfaction and the outcome of soft tissue injuries in an adult emergency department. Emergency Medical Journal, 23(5), 384-387.

14. Richardson, B., Shepstone, L., Poland, F., Mugford, M., Finlayson, B., \& Clemence, N. (2005). Randomised controlled trial and cost consequences study comparing initial physiotherapy assessment and management with routine practice for selected patients in an accident and emergency department of an acute hospital. Emergency Medical Journal, 22(2), 87-92.

15. Kilner, E., \& Sheppard, L.A. (2010). The role of teamwork and communication in the emergency department: A systematic review. International Emergency Nursing, 18(3), 127-137.

16. Lefmann, S.A., \& Sheppard, L.A. (2014). Perceptions of emergency department staff of the role of physiotherapists in the system: A qualitative investigation. Physiotherapy, 100(1), 86-91.

17. Lebec, M.T. (2010). Emergency department physical therapist service: A pilot study examining physician perceptions. Internetional Journal of Allied Health Sciences and Practice, 1(January), 1-9.

18. Lee, K., \& Sheppard, L. (1998). An investigation into medical students' knowledge and perception of physiotherapy services. Australian Physiotherapy, 44(4), 239-245.

19. Barrett, R., \& Terry, L. (2018). Patients' and healthcare professionals' experiencces and perceptions of physiotherapy services in the emergency department: A qualitative systematic review. International Journal of Emergency Medicine, 11(42), 1-10.

20. SurveyMonkey Inc. San Mateo, CA: SurveyMonkey. URL: www.surveymonkey.com [September 2019].

21. Desjardins-Charbonneau, A., Roy, J.S., Thibault, J., Ciccone, V.T., \& Desmeules, F. (2016). Acceptability of physiotherapists as primary care practitioners and advanced practice physiotherapists for care of patients with musculoskeletal disorders: A survey of a university community within the province of Québec. BMC Musculoskeletal Disorders, 17(1), 400-408.

22. Matifat, E., Perreault, K., Gagne, M., Leveille, M., \& Desmeules, F. (2018). Medication recommendation by physiotherapists: A survey of Québec physiotherapists' opinions regarding a new interprofessional model of care with pharmacists. Journal of Evaluation Clinical Practice, 24(3), 480-486.

23. Tung, M., Sharma, R., Hinson, J.S., Nothelle, S., Pannikottu, J., \& Segal, J.B. (2018). Factors associated with imaging overuse in the emergency department: A systematic review. American Journal of Emergency Medecine, 36(2), 301-309.

24. Mills, A.M., Raja, A.S., \& Marin, J.R. (2015). Optimizing diagnostic imaging in the emergency department. Academic Emergency Medecine, 22(5), 625-631.

25. Gagnon, R.P.K, Berthelot, S., Laroche, M.C., Van Neste, C., Achou, B., Desmeules, F., Tremblay, S., \& Hébert, L.J. (2019). Direct access to a physiotherapist in an emergency department as an effective solution to manage MSK disorders: Results from a randomized controlled trial. Annual Meeting of the North American Primary Care Research Group, November 16-20, 2019, Toronto, ON. 


\section{JRIPE}

11

The Acceptability of Emergency Department Physiotherapy

Matifat, LavoieCôté, Kounda, Charrier, Perreault, \& Desmeules

\section{Appendix 1: Email invitation}

Dear members,

Physicians and residents working in Emergency departments (ED) are invited to participate to a study aiming to evaluate perception of acceptability of physiotherapists in ED.

In other countries, physiotherapists can autonomously care for patients suffering from minor musculoskeletal disorder and presenting to an emergency department (ED). In this new model of care, called Advanced Practice in Physiotherapy, physiotherapists can treat patients without the need of a physician's intervention. Considering emergency departments overcrowding in the province of Quebec, integration of physiotherapists in such models of care could be an efficient option to improve access to quality care in EDs. Regarding this new model of care, we want to know the opinion of Quebec's emergency physicians and evaluate the acceptability of implementing physiotherapists in the EDs.

This study is conducted by Lorie Charrier, Nabila Kounda, Pascale Lavoie-Côté, master's students in the physiotherapy program of the University of Montreal under the supervision of François Desmeules, pht, $\mathrm{PhD}$, associate professor at the Rehabilitation School of the University of Montreal and researcher at MaisonneuveRosemont Hospital Research Center.

To assess your perception of the implementation of physiotherapists in EDs, we would like to invite you to participate in a short survey of about 15 minutes. All your answers will be anonymous. This project was approved by the Health Research Ethics committee of the Maisonneuve-Rosemont Hospital (\# 2020-1928).

For questions relative to this project, please contact Lorie Charrier, master student in physiotherapy, at the following email address: lorie.charrier@umontreal.ca or Dr. François Desmeules, pht, PhD, by phone at: 514-343-6791.

Link to the survey: https://fr.surveymonkey.com/r/66LZ57Z

Lorie Charrier, candidate MSc, pht

Nabila Kounda, candidate MSc, pht

Pascale Lavoie-Côté, candidate MSc, pht

François Desmeules, $\mathrm{PhD}$, pht
Journal of Research in
Interprofessional

Practice and

Education

Vol. 11.1

2021 


\section{JRIPE}

12

The Acceptability of Emergency Department Physiotherapy

Matifat, LavoieCôté, Kounda, Charrier, Perreault, \& Desmeules
Journal of Research in Interprofessional Practice and Education
Journal of Research in Interprofessional Practice and Education

\section{Appendix 2: Survey}

The emergency department physicians' perspective on the acceptability of physiotherapists for the care of patients presenting to the emergency department

This study is a quantitative survey study on the perception of emergency department (ED) physicians regarding physiotherapy for the care of patients presenting to the ED. This survey is for physicians and for residents working in EDs.

All answers are confidential and no information that may allow your identification will be collected.

The survey takes about 15 minutes to complete.

The survey is divided into four sections:

1. Demographic data and description of your ED work practice

2. Work experience in collaboration with ED physiotherapists

3. Perceptions and acceptability of ED physiotherapists with a usual scope of practice

4. Perceptions and acceptability of advanced practice ED physiotherapy

The emergence of physiotherapy care in emergency departments in recent years makes it now important to survey the various stakeholders about their perception of this type of model of care.

The survey is conducted by Lorie Charrier, Pascale Lavoie-Côté et Nabila Kounda, professional master students in physiotherapy at the University of Montreal, under the supervision of Professor François Desmeules, PT, Ph.D.

\section{Section 1: Demographic characteristics and description of your ED work context}

This section aims to determine your demographic characteristics and specify the context in which you are practising in an ED.

1 . What is your gender?
a. Male
b. Female
c. Other
d. Prefer not to answer

2. What is your age?
a. 18 - 24 years
b. 25 - 34 years
c. $35-44$ years
d. $45-54$ years
e. $55-64$ years
f. $\geq 65$ years 


\section{JRIPE}

The Acceptability of Emergency Department Physiotherapy

Matifat, LavoieCôté, Kounda, Charrier, Perreault, \& Desmeules
Journal of Research in Interprofessional Practice and Education

\section{Journal of Research in Interprofessional Practice and Education}

3. What is your certification?

a. Collège des médecins de famille du Canada sans compétence avancée en médecine d'urgence (CCMF)

b. Collège des médecins de famille du Canada avec compétence avancée en médecine d'urgence (CCMF-MU)

c. Collège royal des médecins et chirurgiens du Canada (FRCPC)

d. Résident en spécialité d'urgence, en médecine familiale ou MU3

e. Other (specify)

4. In which region do you primarily practice in an ED?
a. Abitibi-Témiscamingue
b. Bas Saint-Laurent
c. Capitale Nationale
d. Centre du Québec
e. Chaudière-Appalaches
f. Côte-Nord
g. Estrie
h. Gaspésie-Îles-de-la-Madeleine
i. Lanaudière
j. Laurentides
k. Laval
1. Mauricie
m. Montérégie
n. Montréal
o. Nord du Québec
p. Outaouais
q. Saguenay-Lac-St-Jean

5. For how long have you been practicing in an emergency department?
a. Less than a year
b. Between 1 and 4 years
c. Between 5 and 9 years
d. Between 10 and 20 years
e. Over 20 years

6 . In the past 12 months, what proportion of your work activities did you dedicate to emergency medicine?
a. $0-24 \%$
b. $25-49 \%$
c. $50-74 \%$
d. $75-100 \%$
e. I don't know 


\section{JRIPE}

14

The Acceptability of Emergency Department Physiotherapy

Matifat, LavoieCôté, Kounda, Charrier, Perreault, \& Desmeules
Journal of Research in Interprofessional Practice and Education
7. Do you primarily practice in a University Affiliated Center (CHA) or University Center (CHU)?
a. Yes
b. No
c. I don't know

8. Is the emergency department where you primarily work, a designated trauma center?
a. Yes
i. it is a primary trauma care center
ii. it is a secondary trauma care center
iii. it is a tertiary trauma care center
iv. I don't know

b. No

9. Are you a member of the following professional associations?
a. I am a member of AMUQ only (l'Association des médecins d'urgence du Québec)
b. I am a member of ASMUQ only (l'Association des spécialistes en médecine d'urgence du Québec)
c. I am a member of both associations AMUQ and ASMUQ

Section 2: Experience working in collaboration with ED physiotherapists The following questions are based on your experience working with physiotherapists in an $\mathrm{ED}$.

10. In the past 12 months, how often did you work in collaboration (case discussion, orientation and elaboration of treatment plans or joint interventions) with a physiotherapist in the ED or from your institution or hospital?
a. Frequently
b. Occasionally
c. Rarely
d. Never
e. I don't know

11. In the past 12 months, how often did you refer patients to the emergency department physiotherapist or to a physiotherapist from your institution or hospital? (Do not consider referral to private practice physiotherapist)
a. Frequently
b. Occasionally
c. Rarely
d. Never
e. I don't know 


\section{JRIPE}

The Acceptability of Emergency Department Physiotherapy

Matifat, LavoieCôté, Kounda, Charrier, Perreault, \& Desmeules
Journal of Research in Interprofessional Practice and Education
Journal of Research in Interprofessional Practice and Education

Section 3: Perceptions and acceptability of ED usual physiotherapy care In the usual physiotherapy model of care currently in place in the province of Québec, the ED physiotherapist evaluates and treats patients after they are assessed by a physician and after obtaining a referral.

The questions in this section refer to this usual physiotherapy model of care as a secondary contact provider in EDs.

12. What is your opinion regarding the overall competency of physiotherapists in all practice areas?
a. Very competent
b. Competent
c. A little competent
d. Not competent at all
e. I don't know

13. What is your opinion regarding the overall competency of physiotherapists in an ED clinical setting?
a. Very competent
b. Competent
c. A little competent
d. Not competent at all
e. I don't know

14. How confident are you regarding the capacity of a physiotherapist to give efficient and safe treatments in EDs?
a. Extremely confident
b. Very confident
c. Moderately confident
d. A little confident
e. Not at all confident
f. I don't know

15. For what type of health conditions do you think it is relevant to refer to an ED physiotherapist? Choose all answer(s) that may apply.
a. Minor musculoskeletal disorder (for example: spinal pain, joint sprain or tendinopathy)
b. Balance disorder
c. Neurological disorders (TBI, Stroke)
d. Mobility disorders and falls
e. Geriatric disorders and deconditioning
f. Respiratory disorders
g. Other (specify) 


\section{JRIPE}

16

The Acceptability of Emergency Department Physiotherapy

Matifat, LavoieCôté, Kounda, Charrier, Perreault, \& Desmeules
16. Usual physiotherapy ED care (after evaluation and initial treatment by an ED physician) is a collaborative model of care which can contribute to improve the care of patients such as reducing the number of treating professionals, diagnostic tests and ED length of stay.
a. Strongly agree
b. Agree
c. Neither agree nor disagree
d. Disagree
e. Strongly disagree
f. I don't know

Section 4: Perceptions and acceptability of advanced practice physiotherapy care in emergency departments

The next questions focus on advanced practice physiotherapy care for patient with minor MSKD (musculoskeletal disorders).

In many countries, physiotherapists can autonomously care for patients suffering from certain minor MSKD and presenting to the ED.

This is a new model of care in which physiotherapists receive additional training and are allowed to perform medical acts normally reserved to physicians such as: the right to make a medical diagnosis, ordering medical imagery (e.g.: radiography and MRI), prescribe medication or perform intra-muscular or intra-articular injections. In those new models of care, the physiotherapist ensures the follow-up of patients and referred to the ED physician or other specialists when needed. As an independent health professional, the advance practice physiotherapist is responsible for the follow-up of patients who where assessed and treated by him.

In the next questions, please indicate your confidence level regarding different aspects of advanced physiotherapy practice as if it were already implemented in the province of Québec and if legislations allowed the delegation of certain medical acts.

17. The advanced practice ED physiotherapist would determine the diagnosis of patients with minor MSKD (low back pain, neck pain, sprain, tendinopathy, muscle pain, etc.) presenting to the ED and in most cases the patient would not need to meet the emergency physician. What would be your level of confidence in an advanced practice physiotherapist in this role?

a. Extremely confident

b. Very confident

c. Moderately confident

d. A little confident

e. Not at all confident

f. I don't know 


\section{JRIPE}

17

The Acceptability of Emergency Department Physiotherapy

Matifat, LavoieCôté, Kounda, Charrier, Perreault, \& Desmeules

Journal of Research in Interprofessional Practice and Education
18. The advanced practice ED physiotherapist would be able to prescribe $\mathrm{X}$-rays, when deemed necessary to properly assess the condition of patients with minor MSKD presenting to the ED (example: to rule out a fracture). What would be your level of confidence in an advanced practice physiotherapist in this role?
a. Extremely confident
b. Very confident
c. Moderately confident
d. A little confident
e. Not at all confident
f. I don't know

19. The advanced practice ED physiotherapist would be able to prescribe imaging tests other than X-rays (such as, MRI, CT-Scan, ultrasound) (to rule out a fracture, a muscular rupture or a tendon rupture), when deemed necessary to properly assess the condition of patients with minor MSKD presenting to the ED. What would be your level of confidence in an advanced practice physiotherapist in this role?
a. Extremely confident
b. Very confident
c. Moderately confident
d. A little confident
e. Not at all confident
f. I don't know

20. The advanced practice ED physiotherapist would refer patients or consult the ED physician when he or she would determined that the patient under his or her responsibility does not suffer from a minor MSKD but would need medical care, (for example: fracture, cauda equina syndrome, myelopathy or a septic arthritis). What would be your level of confidence in an advanced practice physiotherapist in this role?
a. Extremely confident
b. Very confident
c. Moderately confident
d. A little confident
e. Not at all confident
f. I don't know

21. The advanced practice ED physiotherapist could perform either intramuscular or intra-articular injections for the care of patients with minor MSKD presenting to the ED. What would be your level of confidence in an advanced practice physiotherapist in this role?
a. Extremely confident
b. Very confident
c. Moderately confident
d. A little confident 


\section{JRIPE}

The Acceptability of Emergency Department Physiotherapy

Matifat, LavoieCôté, Kounda, Charrier, Perreault, \& Desmeules
Journal of Research in Interprofessional Practice and Education
Journal of Research in Interprofessional Practice and Education

e. Not at all confident

f. I don't know

22. The advanced practice ED physiotherapist could prescribe certain medication such as non-steroidal anti-inflammatories or analgesics, excluding opioids, for the care of patients with minor MSKD presenting to the ED. What would be your level of confidence in an advanced practice physiotherapist in this role?
a. Extremely confident
b. Very confident
c. Moderately confident
d. A little confident
e. Not at all confident
f. I don't know

The questions 25 to 29 are intended to determine your level of agreement with the following statements:

23. Advanced practice physiotherapy is collaborative model of care that could contribute to improve the care of patients with minor MSKD presenting to the ED by reducing the number of treating professionals, diagnostic tests and ED length of stay.
a. Strongly agree
b. Agree
c. Neither agree nor disagree
d. Disagree
e. Strongly disagree
f. I don't know

24. Advanced practice physiotherapy could efficiently care for patients with minor MSKD presenting to the ED (reducing pain level and improving patients' function).
a. Strongly agree
b. Agree
c. Neither agree nor disagree
d. Disagree
e. Strongly disagree
f. I don't know

25 . The initial management by an advanced practice ED physiotherapist could reduce the number of imaging tests prescribed for patients with minor MSKD presenting to the ED.
a. Strongly agree
b. Agree
c. Neither agree nor disagree
d. Disagree
e. Strongly disagree
f. I don't know 


\section{JRIPE \\ Journal of Research in Interprofessional Practice and Education}

19

The Acceptability of Emergency Department Physiotherapy

Matifat, LavoieCôté, Kounda, Charrier, Perreault, \& Desmeules
26. The initial management by an advanced practice ED physiotherapist could reduce wait times for patients with minor MSKD presenting to the ED.
a. Strongly agree
b. Agree
c. Neither agree nor disagree
d. Disagree
e. Strongly disagree
f. I don't know

27. The initial management by an advanced practice ED physiotherapist of patients with minor MSKD presenting to the ED would allow physicians to have more time to care for patients that require medical attention.
a. Strongly agree
b. Agree
c. Neither agree nor disagree
d. Disagree
e. Strongly disagree
f. I don't know 